\title{
THE CHIEF JUSTICE CLINTON J. FORD MOOT COURT COMPETITION
}

\author{
R. A. Lundrigan
}

Chief Justice Clinton J. Ford has always shown considerable interest in law students. Pursuant to his desire to contribute something to benefit them, the Chief Justice Clinton J. Ford Moot Court Competition was establish. ed. The evening of December 2nd, 1960, was the culmination of the first annual competition which actually commenced in the autumn of 1959. Chief Justice Ford as well as the Faculty of Law felt that a moot court com. petition would not only stimulate a great deal of interest on the part of the students in the work of their intended profession, but would also encourage a general excellence in the regular moot court sessions participated in by all students each year. Accordingly, it was planned that the competition would be held in the Edmonton Court House, judged by a panel of three, at least one of whom would be a judge of the Supreme Court of Alberta. Chief Justice Ford donated the trophy, which is presently displayed in the Law Library at the University, and he offered individual plaques for the winners.

The competition began in the autumn of 1959, when the second year law class was told that from the regular moots ten students would be chosen to participate in the semi-finals to be held in March of 1960 . The choices were to be made on the basis of the quality of the factums and on the style and persuasiveness of argument. Each of the semi-finalists presented to the faculty members a five minute argument on one side or the other of a short moot point. From this, four finalists were chosen. Miss Patricia Toombs, Samuel Baker, Robert Lundrigan, and Pierre Mousseau were successful at this second elimination, and thus participated in the final on December 2.

The judges of the moot court were, Chief Justice Clinton J. Ford, who presided, F. J. Newson, Q.C., and W. G. Morrow, Q.C. The Chief Justice presented the trophy to the University President, Walter $H$. Johns, as well as individual plaques to the two winners, Sam Baker and Bob Lundrigan, immediately following the hearing and determination of the case.

The problem used for the final competition involved mistake with regard to the identity of the parties to an alleged contract. More particularly, the facts of a recent English Court of Appeal decision, Ingram and others v. Little were adopted.

In the case, three women, wishing to sell their Renault Dauphine car, advertised it for sale in a newspaper. A rogue, masquerading as one P. G. $H$. Hutchinson of Stanstead House, Caterham, offered to buy the car from the women, payment being by cheque. Initially this offer was rejected because of the risk involved in accepting a cheque as payment. One of the women found

'[1960] 3 W.L.R. 40 S. 
the name "P. G. M. Hutchinson" in the phone directory being listed as living at the address described by the rogue. This fact caused the women to change their minds and to accept the cheque in exchange for the car. The inevitable happened, the cheque was dishonored, and the car was sold by the rogue to a bona fide purchaser for value. The women brought action against the latter for return of the car or alternatively for damages for conversion. They contended that the rouge never obtained property in the car so as to be able to pass title to another, that they made a fundamental mistake with regard to the identity of the person with whom they were dealing and that therefore, no contract was formed. Slade, J. at trial accepted this contention which was affirmed by the English Court of Appeal, Devlin, L.J. dissenting.

The real issue involved in the case was whether there was a mistake with regarded to identity or merely a mistake as to attributes. This case is especially difficult because the parties were dealing inter praesentes, and although this fact is not indisputable evidence that the parties had full intention to deal with the persons before them, it raises a presumption that is very difficult to rebut. A clear case in which this presumption would be re. futed is a situation in which a person were disguised in appearance and in dress so as clearly to represent someone else. Here again, the question in this case would be whether the rogue somehow disguised himself and whether the women, as reasonable people, relied on the identity of the person as disguised. In Hardman v. Boot $h^{2}$ the circumstances were somewhat similar. The mistaken party was dealing inter praesentes with a firm owner's brother, who said that he was a member of the firm. It was there held the mistake was operative. On the other side of the borderline is Phillips v. Brooks" where the rogue selected jewellry in a shop, offering to pay for it by cheque, announcing himself to be a reputable man of title at a certain address. The two possible solutions discussed in that case, which equally apply to the present case are that the vendor either intended to sell the jewellry to the person present in the shop, whoever he was, or he intended to sell to the man of title and to nobody else. The court adopted the first solution.

It should be noticed that in solving problems of mistake like these, the courts endeavor to ascertain the intentions of the parties. Whereas Pothier's test," which is a subjective approach for determining intention, has been resorted to by several English Courts," perhaps Goodhart's objective test" is better. The English Court of Appeal in the Ingram case continually referred to Goodhart in rendering its judgment. Goodhart says," "The test is, has $B$ so conducted himself that $A$ reasonably believes that $B$ is entering into the contract on the understanding that he is not $B$. . This objective reasonable man test when applied to all of the decided cases on mistaken identity seems to provide the most satisfactory explanation.

This discussion of mistake regarding identity of the parties has so many

"1 H. \& C. 804.

3[1919] 2 K.B. 243.

"As quoted and applied in Lake v. Simmons [1927] A.C. 487 and Sowler v. Potter [1939] 4 All E.R. 478.

See note 4.

(1941) 57 L.Q.R. 228.

IId. at p. 242. 
ramifications that it could be continued indefinitely. It is sufficient to say that the English Court of Appeal held the mistake to be operative on the basis of Goodhart's test. The judges of the Moot Court final, however, unanimously held that the mistake was not fundamental and therefore not operative; that the women intended to deal wih he person before them whoever he was. 